\title{
Raw Milk Composition of Crossbred Cows and Correlation Between Milk Constituents in Selected Districts of Chhattisgarh, India
}

\author{
Choodamani Chandrakar ${ }^{1}$, Praveen Kumar ${ }^{1}$, Sanjay Shakya ${ }^{1}$, Sudhir Kumar Jaiswal ${ }^{*}$, Monika ${ }^{3}$ and Upendra Wasist ${ }^{4}$ \\ ${ }^{1}$ Dept. of Veterinary Public Health \& Epidemiology, ${ }^{3}$ Dept of Veterinary Pharmacology and Toxicology, ${ }^{4}$ Dept. of Livestock \\ and Production Management, College of Veterinary Science \& Animal Husbandry, Anjora, Durg, C.G. (491 001), India \\ ${ }^{2}$ Division of poultry Science, Indian Veterinary Research Institute, Izatnagar, Bareilly, U.P. (243 122), India
}

\section{Corresponding Author}

Sudhir Kumar Jaiswal

e-mail: sjsudhirjaiswal009@gmail.com

\begin{abstract}
Article History
Article ID: AR1845

Received in $07^{\text {th }}$ September, 2017

Received in revised form $29^{\text {th }}$ November, 2017

Accepted in final form $7^{\text {th }}$ December, 2017
\end{abstract}

\begin{abstract}
The present study was carried out in four districts of Chhttisgarh to determine the quality of raw milk in this region. A total of 92 milk sample from crossbred cattle was collected and analysied for physico-chemical properties. The ANOVA analysis revealed that there is a significant difference $(p<0.05)$ in all physico-chemical parameters among the districts, difference was non-significant in case of lactose percentage and Density. The overall mean percentages of fat, solid non-fat (SNF) and protein obtained were 3.812 $\pm 0.043,8.444 \pm 0.048$ and $3.412 \pm 0.036$ in that order. Durg districts recorded highest fat and snf content in comparisons to other district of study. In this study, highly significant $(p<0.01)$ positive correlation was observed between fat and SNF (0.792), fat and protein $(0.330)$ and fat and lactose (0.482). Correlation between SNF with protein ( 0.333 ) and lactose $(0.345)$ were found to be positive and highly significant $(p<0.01)$. Density showing non-significant correlation with all the milk constituent parameters. Efforts should be taken to change nutritionand management aspects in such a manner that quality parameter of milk is improved.Values of genetic correlations between productions have huge importance in selection of cows, as they provide possibility for selection of heads on more traits at the same time.
\end{abstract}

Keywords: Crossbred, physico-chemical, lactose, SNF, correlation

\section{Introduction}

Milk is a highly nutritious food and is a good source of different nutrients and hence important for growth, repairs and provides energy. It is a well-established fact that consumers want clean, wholesome and nutritious food that is produced and processed in a sound, sanitary manner and is free from pathogens. Hence, for fulfilling consumer's demand, quality milk production is necessary. Now a day's milk pricing system has shifted from mere quantity to its composition also, affecting the farm income directly. Many farmers have issues regarding low fat and SNF in dairy cow's milk and addressing this issue is need of the hour (Abraham et al., 2015).

The minimum standards for market milks are fixed for fat and SNF contents to ensure quality milk supply to the consumers and to prevent adulteration of milk. Indigenous cattle are being bred with exotic germplasm to increase the milk yield. As the exotic blood level increases there is an increase in the milk yield of the crossbred animals if the animals are in high plane of nutrition. In the underfed animals the milk yield and SNF in milk are low especially in crossbred cows and farmers suffer from low SNF milk (Kumarsen et al., 2008). It is well documented that composition of milk is found to be influenced by many genetic and environmental factors such as parity, breed, stage of lactation and agro-climatic conditions (Sarkar et al., 2006; Krovvidi et al., 2013).

In Chhattisgarh state, milk is produced in urban and rural areas mostly in non-organized way and usually supplied tothe consumers in raw form. Consumers are not much aware about what quality of milk they consume. Keeping all these things in mind the present study was designed to know the compositional quality of crossbred cow raw milk in four districtsof Chhattisgarh.

\section{Materials and Methods}

\subsection{Study area}

Chhattisgarh located in central India, has an area of 135, 194 $\mathrm{km}^{2}$. It extends from the latitude $17^{\circ} 46^{\prime}$ to $24^{\circ} 05^{\prime} \mathrm{N}$ to $80^{\circ} 15^{\prime}$ to $84^{\circ} 23^{\prime} \mathrm{S}$. Chhattisgarh is ranked $10^{\text {th }}$ as per the geographical area. It consist $4.11 \%$ of country's total geographical area and $51.6 \%$ area is cropped. About $80 \%$ of people are engaged in agriculture and allied sectors. 


\subsection{Collection of milk samples}

A total of 92 crossbred cow milk sampleswere collected from the livestock owners and dairy units, from Durg, Rajnandgaon, Raipur and Balod districts of Chhattisgarh. About $50 \mathrm{ml}$ of milk from individual cowwas collected in clean and dry neatly labelled sample containers and transported to laboratory as soon as possible under refrigerated conditions.The milk samples were analysed for various milk constituents'viz. fat, SNF, protein, lactose, density, freezing point and mineral content by LactoStar SN 3510.

\subsection{Statistical analyses}

Data were analysed by SPSS (Statistical Package for Social Science, version 20.00) computer program. Analysis of variance (ANOVA) and Post Hoc (Duncan) were used to determine the statistical difference of milk quality parameters among the different study areas.Pearson correlation was used to analyse the association between coefficient of correlation among different milk constituents. Differences among the districts were tested for significance at $(p \leq 0.05)$ level (Dehinenet et al., 2013).

\section{Results and Discussion}

\subsection{Milk physico-chemical parameter}

\subsubsection{Milk fat percentage}

Milk samples from Durg district tested highest for fat percentage (3.948 \pm 0.085$)$ while that of Rajnandgaon district was lowest (3.639 \pm 0.093$)$ (Table1). There was a significant difference $(p<0.05)$ in fat \% among the study areas and the overall mean value of the fat $(3.812 \pm 0.043 \%)$ in the study area is slightly higher than FSSAI standard value (3.50\%), (FSSAI, 2010). About $30 \%$ of the samples had less than the standard prescribed for cow milk i.e. 3.5\% fat. The results are in agreement with findings of Kumaresan et al., (2008) who reported milk fat per cent ranging from 3.00 to $5.20 \%$ in Jersey and Holstein Friesian crossbred cow in Namakkal district of Tamilnadu they also reported $26.27 \%$ cow milk had fat percent below the FSSAI level. Abraham et al. (2015); Yogi et al. (2017) reported higher fat content than present study, while Swathi et al. (2017) reported lower fat content than present study.
Radhika et al. (2012) reported that location-wise difference in milk fat percentage was statistically significant. The effect of district was highly significant $(p<0.05)$ on all the milk contents and their yields which could be due to the difference in the geographical location of the farms and or the husbandry practices followed.

\subsubsection{Milk solids not fat percentage}

The overall average for SNF percentage was $8.444 \pm 0.048$ and the analysis of variance revealed that districts had very significant effect on SNF and total solids percentage $(p<0.05)$ (Table 1). Among 4 different districts selected, Durg recorded the maximum SNF, whereas Rajnandgaon recorded the minimum SNF. About $50 \%$ of the cross bred milk samples had less than $8.5 \%$ SNF. Similar findings were reported by Radhika et al. (2012) who reported the mean SNF 8.359 \pm 0.042 value in cross bred animal of Kerla and difference in SNF content of various locations. Higher SNF content was reported by Kumaresan et al. (2008); Abraham et al. (2015) but Swathi et al. (2017); Yogi et al. (2017) recorded lower SNF content than present study. Topographical peculiarities and difference in feed ingredients must have resulted in such a significant difference between districts. Also, reducing the energy fed to high-producing cows below requirements may decrease SNF as much as 0.2-0.5 percentage units (Harris and Bachman 1988).

\subsubsection{Milk protein and lactose content}

The overall mean for protein percentage was $3.412 \pm 0.036$ and for lactose was $4.617 \pm 0.047$ the analysis of variance revealed that district had very significant effect on protein percentage but in case of lactose percentage the difference between districts was non-significant. Milk sample from Durg districts recording highest protein percent in all four districts, in case of lactose Raipur districts reported higher value than all other districts. Lowest protein and lactose percent was reported from Rajnandgaon and Balod respectively. Dang and Anand (2007) who reported protein content rangingfrom 3.02 to 3.99 and lactose were found to range from 3.86 to $4.97 \%$ in crossbred cow which was similar with present findings. Yogi et al. (2017) reported slightly lower values for protein and lactose content

Table 1: Physico-chemical properties of cow raw milk in the study area

\begin{tabular}{lccccc}
\hline Parameters & Durg & Rajnandgaon & Raipur & Balod & Over all mean \\
\hline Fat (\%) & $3.948^{\mathrm{a}} \pm 0.085$ & $3.639^{\mathrm{b}} \pm 0.093$ & $3.904^{\mathrm{a}} \pm 0.093$ & $3.758^{\mathrm{ab}} \pm 0.063$ & $3.812 \pm 0.043$ \\
SNF (\%) & $8.643^{\mathrm{a}} \pm 0.089$ & $8.263^{\mathrm{b}} \pm 0.086$ & $8.488^{\mathrm{a}} \pm 0.108$ & $8.381^{\mathrm{ab}} \pm 0.087$ & $8.444 \pm 0.048$ \\
Protein (\%) & $3.544^{\mathrm{a}} \pm 0.058$ & $3.278^{\mathrm{b}} \pm 0.066$ & $3.485^{\mathrm{a}} \pm 0.081$ & $3.342^{\mathrm{ab}} \pm 0.073$ & $3.412 \pm 0.036$ \\
Lactose (\%) & $4.631 \pm 0.081$ & $4.570 \pm 0.112$ & $4.741 \pm 0.078$ & $4.526 \pm 0.104$ & $4.617 \pm 0.047$ \\
Density (g cm $\left.{ }^{-3}\right)$ & $1.028 \pm 0.0007$ & $1.027 \pm 0.0005$ & $1.026 \pm 0.0006$ & $1.028 \pm 0.0013$ & $1.027 \pm 0.0004$ \\
Minerals (\%) & $0.733^{\mathrm{b}} \pm 0.015$ & $0.707^{\mathrm{b}} \pm 0.020$ & $0.865^{\mathrm{a}} \pm 0.024$ & $0.760^{\mathrm{b}} \pm 0.019$ & $0.766 \pm 0.011$ \\
Freezing point $\left({ }^{\circ} \mathrm{C}\right)$ & $-0.528^{\mathrm{bc}} \pm 0.013$ & $-0.516^{\mathrm{c}} \pm 0.012$ & $-0.565^{\mathrm{a}} \pm 0.014$ & $-0.553^{\mathrm{ab}} \pm 0.007$ & $-0.541 \pm 0.006$ \\
\hline
\end{tabular}

Mean with different superscript within a row differed significantly from each other $(p<0.05)$. 
for HF cross cattle. Variation in protein and lactose content of various districts may be due to different managemental practices adopted by farmers as well as environmental and health condition of animal is other factor which affecting milk composition. According to Jones and Jones (1986) low milk fat and low milk protein were considered as possible predisposing factors to bovine Escherichia coli mastitis.

\subsubsection{Milk density, mineral percent and freezing point}

The overall mean for density, mineral percent and freezing point were $1.027 \pm 0.0004,0.766 \pm 0.011$ and $-0.541 \pm 0.006{ }^{\circ} \mathrm{C}$. Milk composition is an important characteristic in dairycattle. Density and mineral percent of cross bred cow milk showing non-significant variation among the different study region where as freezing point recorded in present study was showing statistically significant $(p<0.05)$ difference among the study districts. Abraham et al. (2015) reported density and mineral percent of cross bred HF was $1.029 \pm 0.52$ and $0.69 \pm 0.01$ respectively which was nearly similar with present value. Senevirathne et al. (2015) recorded nearly similar finding for the freezing point of HF cross cattle. The freezing point of milk is an important indicator of the milk quality. Zagorska and Cipovica (2013) reported that the freezing point of milk was affected by the freezing of milk during cooling, or addition of rinse water to the tank in most cases.

\subsection{Correlation between different milk constituents}

Table 2 Shows correlation coefficients between the different milk quality parameters. In this study, highly significant $(p<0.01)$ positive correlation was observed between fat and SNF (0.792), fat and protein (0.330) and fat and lactose (0.482). Correlation between SNF with protein $(0.333)$ and lactose $(0.345)$ were found to be positive and highly significant $(p<0.01)$. There exists a positive and significant $(p<0.01)$ correlation between protein and lactose. Negative but nonsignificant correlation was reported in between density and all the milk constituents in present study. Mineral content of milk showing non-significant positive correlation with all the parameters except with Density. Freezing point of milk showing non-significant positive correlation with SNF,

Table 2: Pearson Correlation coefficients between different milk constituents in different districts

\begin{tabular}{|c|c|c|c|c|c|c|c|}
\hline Variable & Fat & SNF & Protein & Lactose & Density & Minerals & Freezing Point \\
\hline Fat & 1 & $0.792^{* *}$ & $0.330^{* *}$ & $0.482^{* *}$ & -0.091 & 0.051 & -0.030 \\
\hline SNF & & 1 & $0.333^{* *}$ & $0.345^{* *}$ & -0.028 & 0.172 & 0.014 \\
\hline Protein & & & 1 & $0.417^{* *}$ & -0.107 & 0.126 & 0.059 \\
\hline Lactose & & & & 1 & -0.097 & 0.020 & -0.052 \\
\hline Density & & & & & 1 & -0.174 & -0.125 \\
\hline Minerals & & & & & & 1 & .205 \\
\hline Freezing point & & & & & & & 1 \\
\hline
\end{tabular}

${ }^{* *}$ Pearson correlation is significant $(p=0.01)$ level (2-tailed)

Protein and Minerals as well as negative correlation with Fat, Lactose and Density. Highly significant $(p<0.01)$ correlation was observed fat percentage and SNF percentage, fat and protein percentage and fat and lactose percentage. This is supported by findings of (Yoon et al., 2003; Yogi et al., 2017). These correlations suggest that as the fat increased, there were tendency for, SNF, protein and lactose to increase. Thus selection for fat will automatically bring improvement in TS, SNF, protein and lactose contents of milk in cross bred cows. This information will be highly valuable in breeding plan to improve these parameters. Non-significant correlation of Density to milk Fat percentage and Freezing point is supported by Dehinenet et al. (2013).

\section{Conclusion}

Milk constituents like milk fat and solids-not-fat (SNF) decide the economics of dairy cattle rearing. Crossbred cattle of alldistricts are performing comparatively well in terms of Fat percentage but in terms of SNF content majority of districts have below prescribed limit of SNF. Many reasons mentioned abovemay be responsible for reduction in the SNF content of milk. Efforts should be taken to change nutrition and management aspects in such a manner that SNF content of milk is improved. The correlations suggest that as the fat increased, there were tendency for, SNF, protein and lactose to increase. Thus selection for fat will automatically bring improvement in SNF, protein and lactose contents of milk in cross bred cows.

\section{Acknowledgement}

Authors are thankful to College of Veterinary Science andAnimal Husbandry Anjora, Durg, Chhattisgarh.

\section{References}

Abraham, B.L., Gayathri, S.L., 2015. Milk composition of crossbred and desi cattle maintained in the sub-tropical high ranges of kerala. Indian Journal of Veterinary and Animmal Sciences Research 44(1), 53-55.

Dang, A.K., Anand, S.K., 2007. Effect of milking system on the milk somatic cell counts and composition, Livestock Research for Rural Development, 19(6). 
Dehinenet, G., Mekonnen, H., Ashenafi, M., Emmanuelle, G., 2013. Determinants of raw milk quality under a smallholder production system in selected areas of Amhara and Oromia National Regional States, Ethiopia. Agriculture and Biology Journal of North America 4(1), 84-90.

Harris, B., Bachman, K.C., 1988. Genetic and non-genetic factors affecting milk yield and composition. University of Florida, IFAS Extension. Publication DS, 25.

Jones, T.O., Jones, P.C., 1986. Cow milk yield and composition before development of Escherichia coli mastitis. The Veterinary record 119(13), 319-321.

Kumaresan, G., Saravanakumar, K., Murugan, B., Rajendran, D., Devendran, P., Annal Villi, R., 2008. Finely ground dry corn supplementation to improve solids not fat content of crossbred cattle milk during summer under tropical climate. Journal of Applied Sciences Research 4(2), 202-206.

Radhika, G., Ajithkumar, S., Rani, A., Sathian, C.T., Anilkumar, K., Usha, A.P., Dinesh, C.N., 2012. Milk yield and composition of crossbred cows in the hilly Wayanad district of Kerala, India. Indian Journal of Animal Sciences 82(10), 1251-1254.

Sarkar, U., Gupta, A.K., Sarkar, V., Mohanty, T.K., Raina, V.S., Prasad, S., 2006. Factors affecting test day milk yield and milk composition in dairy animals. Journal of dairying, foods \& home sciences 25(2), 129-13.
Senevirathne, P.G.N.D., Mangalika, U.L.P., Adikari, A.M.J.B., Nayananjalie, W.A.D., 2016. Evaluation of Cow Factors and Milk Composition on Freezing Point Depression of Cow Milk. International Journal of Livestock Research 6(5), 61-67.

Sudhakar, K., Panneerselvam, S., Thiruvenkadan, A.K., Abraham, J., Vinodkumar, G., 2013. Factors effecting milk composition of crossbred dairy cattle in southern India. International Journal of Food, Agricultural Veterinary Science 3(1), 229-33.

Swathi, Y., Reddy, Y.R., Babu, D.S., Rao, D.S., 2017. Compositional quality of crossbred cow raw milk in rural and urban areas of YSR Kadapa district. International Journal of Science, Environment and Technology 6(2), 1256-1259.

Yogi, S., Chourasia, S.K., Sahu, S.S., Jaiswal, S., 2017. Correlation between milk constituents and somatic cell counts in holsteinfriesian crossbred cattle.International Journal of Agriculture Sciences 9(7), 3840-3842.

Yoon, J.T., Lee, L.J., Kim, C.K., Chung, Y.C., Kim, C.H., 2004. Effects of milk production, season, parity and lactation period on variations of milk urea nitrogen concentration and milk components of Holstein dairy cows. Asian Australasian Journal of Animal Sciences 17(4), 479-484.

Zagorska, J., Ciprovica, I., 2013. Evaluation of Factors Affecting Freezing Point of Milk International Scholarly and Scientific Research \& Innovation 7, 389-394. 